\title{
The Influence of Sponsored Post Towards The Urge to Buy Implusively on The Information Technology System of The Social Media of Instagram
}

\author{
Anggrainni Rahayu ${ }^{1, a *}$, Zaki Baridwan ${ }^{1 . b}$ \\ ${ }^{1}$ Department of Accounting, Faculty of Economics and Business, Universitas Brawijaya \\ Jl. MT. Haryono No. 165 Malang \\ East Java, Indonesia \\ e-mail: ${ }^{\mathrm{a} *}$ anggrainni.rahayu@gmail.com, ${ }^{\mathrm{b}}$ zaki@ub.ac.id \\ * Corresponding Author
}

\begin{abstract}
This study examines the influence between variables of similarity, vicarious expression, aesthetic appeal, cognitive trust, affective trust, product affection, and urge to buy impulsively on the social media of Instagram. The method used for collecting the data in this study was the survey method. The samples were collected using the convenient sampling techniques. The utilized data analysis techniques used in this study were validity testing, reliability testing, and hypothesis testing. The data analysis process was conducted with the aid of Partial Least Square (PLS). The results of this study showed that similarity positively influences cognitive and affective trust, vicarious expression and aesthetic appeal positively influence product affection, cognitive trust positively influences affective trust, affective trust positively influences product affection, cognitive trust does not influence the urge to buy impulsively, and affective trust and product affection positively influence the urge to buy impulsively.
\end{abstract}

Keywords: Instagram, Recommender, Sponsored post, urge to buy impulsively

Article History: Received: July, 22019 Revised: February, 212020 Accepted: September, 72020

How to cite: Rahayu, A., \& Baridwan, Z. (2020). The Influence of Sponsored Post Towards The Urge to Buy Implusively on The Information Technology System of The Social Media of Instagram. Akrual: Jurnal Akuntansi, 11(2):95-109. DOI: https://doi.org/10.26740/jaj.v11n2.p95-109

\section{INTRODUCTION}

Today's technology development is growing up so fast. A lot of human's activity has been digitalized to make it easier. It is like the interaction between the people that digitalized through social media. Social media is a technology or application which is used by people to developing and maintaining their social networking sites (Albarran, 2013). A lot of individuals using social media to interact with other person and used it to expand the network. The interaction between people through social media makes social media can be one of the media that is useful for a business. A lot of business use social media as a potential place to sell the product. Business like business to consumer type or consumer to consumer type has been using social media as a market to sell their product.

With the development of social commerce, a lot of people starting to promote their business through social media. The social media developer sees this promoting activity as an opportunity 
to build a feature that allows people to promote their business through social media. One of the popular social media used as social commerce media is Instagram. Instagram is a social media that allow the user to share their photo or video for free to another user. Instagram also has a feature that can help their user to promote the user's photo or video that is called sponsored post feature. This study is trying to find out how the influence of the promoting feature (sponsored post) of social media of Instagram, can impact the urge of the Instagram user to buy impulsively. Impulsive buying is a sudden realistic attitude related to the emotional preference when people went shopping (Sofi \& Nika, 2016). Impulsive buying is also identified as an attitude when people buy something without any plan before. The reason why this issue is important is that the starting objective of social media user when they access social media is to make interactions between another user. However, since there is a feature like a sponsored post, it makes the social media user have another objective when they access social media. One of them is to do shopping, either it is impulsively or not. In this study, the effect of a sponsored post is visible from (1) the effect of similarity towards affective trust and cognitive trust and (2) the influence of aesthetic appeal and vicarious expression toward the Instagram user product affection.

This study also can be used as information related to the management accounting system. The management accounting system could provide the information to complete the specific management objectives (Hansen \& Mowen, 2007). The management accounting system has three objectives: (1) Provide information related to the cost of the service, product, and another object related to management, (2) Provide information related to planning, controlling, evaluation, and continuous development, and (3) Provide information related to decision making.

In this case, this study can be useful as information for planning or decision making. This study also can give the information related to the element that possibly affects the urge of impulsive buying which is useful for a person who decides to promote their product through sponsored post feature in the social media of Instagram. A person tendency of having an urge to buy impulsively can be useful as an opportunity for a business person to gain revenue. One of the characteristics of the information used in management accounting is that it is not always financial information (Hansen \& Mowen, 2007). It strengthens the assumption that this study is useful as the information used for the management accounting system. The information used in management accounting is beneficial for product design, production, marketing decision, and performance evaluation (Horngren, 2012).

The influence of similarity towards affective trust and cognitive trust to the recommender. The research between people who do not know each other, support the similarity hypothesis which explains that the more people similar, the more the interaction between them (Morry, 2005). The similarity can include similarity between demographics, characteristics, backgrounds, experiences, and interests. In this study, the similarity described by the similarity between Instagram users that seen sponsored post and the recommender who used a sponsored post feature. The recommender is Instagram user behind the account that promoting their content through sponsored post feature. In social media, individual will tend to trust another similar individual (Hayashi \& Kryssanov, 2013). 
Related to the trust, this research divide trust into two categories those are cognitive trust and affective-trust. Cognitive trust is related to the valuation given by the consumer to the parties who provide products or services including the process of considering the benefit and the risk of trusting the parties. The affective-trust is related to the emotional bonding between the consumer that emphasize consumer well-being and also can be associated with consumer intentions (Calefato, Lanubile, \& Novielli, 2015).

This study is trying to discover the influence of similarity within the cognitive trust and affective trust. As explained before, the similarity between one individual to the others can influence the trust between them. In this case, this study trying to discover the influence of similarity between the Instagram user and the recommender towards the Instagram user cognitive and affective trust to the recommender. The research about similarity, cognitive trust, and affective-trust conclude that similarity is positively influencing the cognitive trust and the affective-trust. Chen et al., (2019) also done the research related to the variable and conclude that similarity is positively influencing the cognitive trust and affective trust. Therefore, this study and then propose hypotheses:

H1a: The similarity positively influences consumer cognitive trust to the recommender. H1b: The similarity positively influences consumer affective-trust to the recommender.

The influence of vicarious expression towards product affection

The narration in television advertisement can influence listener emotion and can build empathy (Deighton, Romer, \& McQueen, 1989). It describes the use of a vicarious expression. Vicarious expression refers to the level where the writer can deliver the clear review related to the experience of using the promoted product so that the message can be perceived the reader $(\mathrm{Li}$, Huang, Tan, \& Wei, 2013). The better the quality of a sentence, the easier the reader to get the information delivered by the writer.

The writer objective of writing a vicarious expression is to attract the reader interest so that the reader can have affection related to the product promoted. It can conclude that the better the quality of a sentence, the easier the reader get the information in the sentence. The getting easier the reader take the information in the sentence, the higher the reader's interest in the product promoted in the sponsored post. Therefore, this study assumes that the better caption quality that complements the sponsored post in the Instagram social media, the better the Instagram user who see the sponsored post interest to the product promoted. In this case, the caption is the statement that complements the Instagram post. The research did by Chen et al., (2018), concluded the vicarious expression positively influences product affection. In this case, this study proposes a hypothesis:

\section{H2: Vicarious expression in the sponsored post is positively affecting product affection.}

\section{The influence of aesthetic appeal towards product affection}

In this study, the aesthetic appeal defined as the appeal related to the visual appearance of the sponsored post. Related to the internet, visual appearance can influence the quality of the interaction between online stimuli and the internet user (Shaouf, Lü, \& Li, 2016). Under an online environment, where the consumer can not physically evaluate the product before buying the product, product presentation is essential to stimulate the affective or cognitive response (Yoo \& Kim, 2014). This response will be affecting the result and the shopping experience. 
This study and then assume that aesthetic appeal that visible from visual appearance dan product presentation can influence the consumer affection to the product. Furthermore, this study illustrates the assumption of the sponsored post on Instagram social media. It is related to the aesthetic appeal that is visible from the visual appearance and the product presentation of the sponsored post on Instagram social media, which assumes that it can influence the Instagram user affection to the product sponsored through a sponsored post. In this case, the research did by Chen et al., (2018), concluded the aesthetic appeal positively influences product affection. Therefore, related to the association between aesthetic appeal and product affection, this study proposes a hypothesis:

\section{H3: The aesthetic appeal on the sponsored post positively influences product affection.}

\section{The influence of cognitive trust towards affective trust}

Trust is a multifactorial situation, including cognitive, affective, and behavior intention (Lewicki, Tomlinson, \& Gillespie, 2006). In this case, trust considered as a single factor higher than cognitive, affective, and behavior intention. Cognitive trust provides a basis to the affective trust, the idea related to cognitive trust already exists before the establishment of affective trust (Johnson \& Grayson, 2005).The sociology base of trust also built through emotional basis that complements the cognitive base (Lewis \& Weigert, 1985). The higher the cognitive trust, the higher the affective trust (Huang, 2015).

Therefore, this study assumes that cognitive trust can influence affective trust. The application under this study assumes that cognitive trust is an acceptable valuation to the sponsored post that can be influence the Instagram user impression after saw the sponsored post. This impression represents the term affective trust used in this study. This assumption supported by the research that concluded the cognitive trust positively influences the affective trust (Huang, 2015). In this case, this study proposes a hypothesis:

\section{H4: Cognitive trust positively affects affective trust.}

\section{The influence of affective trust towards product affection}

Signaling theory proposing that trust on recommender have significantly influenced consumer behavior when they have slightly information about the recommender (Chen et al., 2019). Related to the affective trust, (Huang, 2015), give an example about affective trust through the process that done by the financial consultant when they are trying to attract their potential consumer interest. To attract consumer interest, financial consultant using a strategy of telling the recommendation that can help the consumer to save the transaction cost (Huang, 2015). Through the explanation, the finance consultant builds an emotional bonding with the potential consumer so that it possibly attracts the consumer interest in the service offered. Trust is also base on the kindness from others, it happens when social media user saw the product recommendation, they can assume that a product recommendation is a form of kindness from the recommender that gave the information about the product that possibly beneficial (McEvily, Perrone, \& Zaheer, 2003). This kindness perception can shape the trust of social media user to the recommender as information giver.

Therefore, this study assumes that affective trust that is related to the feeling and emotion can influence someone related to product affection. In this case, affective trust, that is in the form of feeling and emotion, can be applied on the Instagram user affective trust to the sponsored post they have seen. This study assumes, when the Instagram user has affective trust to the sponsored post they have seen, they tend to have an affection to the product promoted in 
the sponsored post. This study and then proposes a hypothesis: H5: Affective trust positively influences the product affection

The influence of cognitive trust, affective trust, and product affection towards urge to buy impulsively.

The urge to buy impulsively is a behavior related to the encouragement to buy without any plan and sudden (Xiao \& Nicholson, 2013). It also can be said that impulsive buying is a respond of a subjective or external push that complemented by the urge that is strong and firm after the consumer has an emotional, cognitive, and behavior reaction that can be a new trigger to repeat the impulsive buying. Cognitive trust is trust towards the reliability and its dependence on others (Huang, 2015). The valuation related to cognitive trust is generally rational and depend on objective information, such as information related to experience or external advice. When a consumer impulsively behaves, they cognitively alert and do not refuse to process the information related (Dholakia, 2000).

The internet media content can trigger specific emotion and encourage user behavior to buy impulsively (Adelaar, Chang, Lancendorfer, Lee, \& Morimoto, 2003). That research also concluded that emotional response from research subject that is internet user have a positive connection towards the urge to buy impulsively. The consumer desire to buy can be increased because of their trust in social media (Hajli, Sims, Zadeh, \& Richard, 2017). On that research, the researcher divide trust into two categories those are cognitive trust and affective trust. The impulsive buyer showed the entertained, happy, and enthusiastic feeling (Beatty \& Ferrell, 1998).

Therefore, this study assumes that cognitive trust can influence the urge to buy impulsively. It is related to the consumer valuation that is objective and rational related to the sponsored post that appears on the Instagram user feed. Other than that, the existence of emotional bonding in the urge to buy impulsively is also related to the affective trust. In other words, the emotional bonding in the urge to buy impulsively is one of the aspects in the affective trust considering that the affective trust is the trust that arises because there is a consumer emotional bonding. Therefore, this study proposes hypotheses:

H6: Cognitive trust positively affects the urge to buy impulsively. H7: Affective trust positively affects the urge to buy impulsively.

The consumer who has positive emotional bonding tend to make a decision quickly and efficiently (Isen, 1984). The urge to buy impulsively defines as the intention of an individual to buy when they see an object (Parboteeah, Valacich, \& Wells, 2009). Furthermore, they will buy the object that interesting according to them. Product attribute contributes to the impulsive buying behavior and that is base on the individual interest to a product (Park, Kim, Funches, \& Foxx, 2012). Therefore, this study assumes that product affection related to the sponsored post on Instagram can encourage the Instagram user who sees the sponsored post to buy impulsively. In this case, this study proposes a hypothesis:

H8: Product affection positively influences the urge to buy impulsively. 


\section{RESEARCH METHOD}

Population and Sample

The population used in this study are the active student of accounting major at Brawijaya University for the year of 2015, 2016, and 2017. Related to the population chosen, according to the official website of Economics and Business Faculty of Brawijaya University (http://feb.ub.ac.id/id/akademik/jumlah-mahasiswa-pertahun), the total student of accounting major for the year 2015, 2016, and 2017 are 867 students. This population chooses based on the consideration that university student is the circle who familiar with social media. In Indonesia, the age of Instagram user generally starting from 18 to 24 years old. Therefore, the university student and then chosen as the population in this study. Remembering that the average of university student age is the same as the average of Indonesia Instagram user age, that is 18 to 24 years old. This study uses the convenience sampling technique. The total sample used in this study is 274 . Related to the sample chosen, the researcher uses an error rate of $5 \%$ or 0,05 .

\section{Data collection method}

The data collection method used in this study is the survey method. The survey or selfadministered survey is the primary data collection method by giving some question to the individual respondent (Hartono, 2013). Chen et al., (2018) research questionnaire used as the questionnaire, in this study. The researchers translate the questionnaire from English to Indonesia before using it. The researcher adjusts the question so that it is suitable for the topic of this study. The adjustment is including adjustment related to the term used in Instagram, remembering that in the Chen et al., (2018) research, they used WeChat social media. Therefore, there is some term that is different between WeChat and Instagram. The primary data used in this study obtained by sending the questionnaire to the respondent either directly or via electronic services.

Research Model

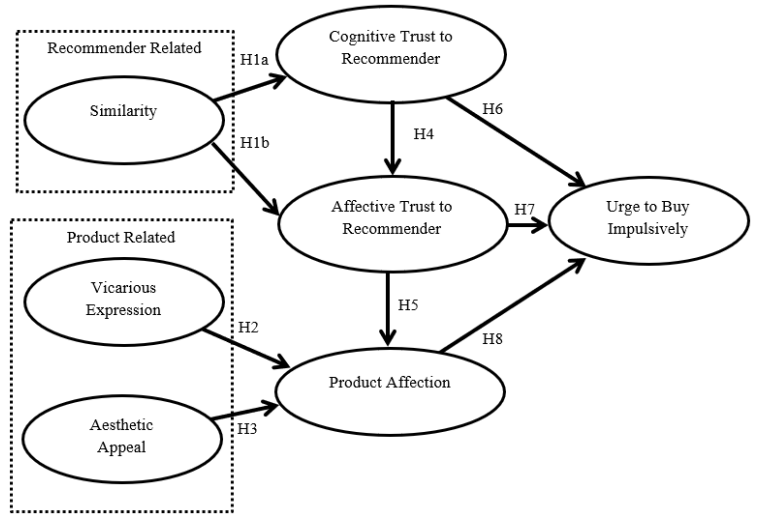

Figure 1. Research Model

\section{RESULTS AND DISCUSSION}

Respondent

The respondent in this study is the active student of accounting major at Brawijaya University year of 2015 to 2017. In the data collection, the researcher used the survey method by spreading the questionnaire directly or online by using google form. The details of the questionnaire data collection shown in Table 1. 


\section{Demographic Characteristics}

In this study, the demographic characteristics illustrate through the chart. The chart describes the respondent distribution according to the respondent characteristics. This study using two demographic characteristics that are gender and age. The gender divides into two categories that are male and female. The age characteristics divide into under 20, between 20 to 25 , and 25 above. The respondent distribution related to gender characteristic shown in Figure 2. The respondent distribution related to age characteristic shown in Figure 3.

Table 1: Questionnaire Data Collection Table

\begin{tabular}{lc}
\hline \multicolumn{1}{c}{ Title } & Total \\
\hline The number of questionnaire spread & 275 \\
The number of questionnaire return & 271 \\
The number of the questionnaire used & 240 \\
The rate of questionnaire return & $98,5 \%$ \\
The rate of the questionnaire used & $87,3 \%$ \\
\hline Source: Processed by researchers
\end{tabular}

Source: Processed by researchers

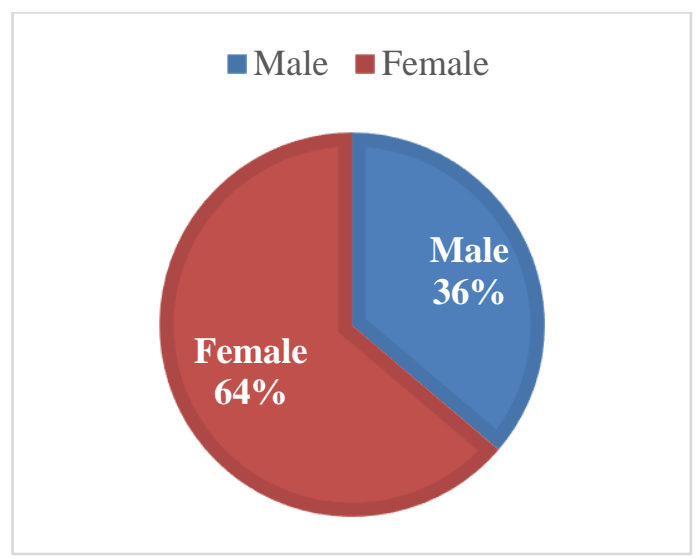

Figure 2: Gender Distribution

घ $<20$ years old $\square 20$ - 25 years old $\square>25$ years old

[CATEG

ORY

NAME]

[PERCE

NTAGE]

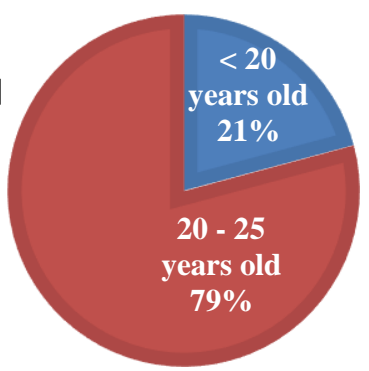

Figure 3: Age Distribution 


\section{Descriptive Statistics}

Descriptive statistics is a statistic about the phenomena or characteristics of research data. The characteristics are the data distribution characteristics used by the researcher (Hartono, 2013). The descriptive statistics shown in this study is including measurement of central tendency and dispersion. The central tendency measurement is used to measure the central values of the data distribution. This study using average or mean to measure central tendency. For the dispersion measurement, this study using deviation standard to measure the dispersion. Dispersion is the measurement used to measure the variability of the data towards the central value. The result of the descriptive statistics measurement shown in Table 2.

\section{The Model Evaluation}

The evaluation related to the research model is using Partial Least Square (PLS) help. This research model evaluation did by using three steps those are including convergent validity, discriminant validity, and reliability test.

\section{Convergent validity}

The values used in the convergent validity are the value of AVE, communality, and loading factor. The AVE and communality value in this study shown in the output criteria overview model table (Table 3). The loading factor value in this study shown in the output outer loading table (Table 4).

When a variable construct has the AVE and communality value more than 0,5 , it can conclude that the variable construct is valid convergently (Abdillah \& Hartono, 2015). When a variable construct has the loading factor score more than 0,7 , it can conclude that the variable construct is valid convergently (Sarstedt, Ringle, \& F. Hair, 2017). Base on Table 3, it is discovered that the AVE and communality value in every variable used in this study are more than 0,5. Related to the loading factor value, based on Table 4, all the construct used in this study have loading factor value more than 0,7 . It can conclude that all the variable construct used in this study are valid convergently.

Table 2: Descriptive Statistics

\begin{tabular}{lccccc}
\hline & N & Min & Max & Mean & Deviation Standard \\
Similarity (S) & 240 & 1 & 7 & 4,62 & 1,14 \\
\hline Vicarious Expression (VE) & 240 & 1 & 7 & 5,29 & 0,98 \\
Aesthetics Appeal (AA) & 240 & 1 & 7 & 5,33 & 1,08 \\
Cognitive Trust (CT) & 240 & 1 & 7 & 4,37 & 1,27 \\
Affective Trust (AT) & 240 & 1 & 7 & 4,66 & 1,06 \\
Product Affection (PA) & 240 & 1 & 7 & 4,67 & 1,09 \\
Urge to Buy Impulsively (UBI) & 240 & 1 & 7 & 4,44 & 1,18 \\
\hline
\end{tabular}

Source: Processed by researcher

Discriminant Validity

Discriminant validity used, when related to the theory, two variables predicted as the noncorrelation variable, and the result of the measurement provides the same result which is noncorrelation variable (Sekaran, 2003). When a variable construct has the cross-loading score more than 0,7 , it can conclude that the variable construct is valid discriminantly (Abdillah \& Hartono, 2015). The cross-loading score used in this study shown in the output cross loading table (Table 
5). Base on Table 5, it is discovered that the cross-loading score of every variable construct used in this study is more than 0,7 . Therefore, it can conclude that the variable constructs used in this study are valid discriminantly.

\section{Reliability}

Reliability from a measurement indicates the level when a result did not contain any bias, and therefore, it confirmed the measurement consistency for long time horizon and on many kinds of instrument (Sekaran, 2003). When a variable construct has the Cronbach's alpha score more than 0,6 and the composite reliability score more than 0,7 , it can conclude that the variable construct is reliable (Abdillah \& Hartono, 2015). The number of Cronbach's alpha and the composite reliability of this study shown in Table 2 . Base on Table 2, it is discovered that the variable construct used in this study has the Cronbach's alpha scores more than 0,6 , and the composite reliability scores more than 0,7 . Therefore, it can conclude that the variable construct used in this study is reliable.

\section{Hypothesis Test}

Hypothesis test in this study, conducted base on the number of T-statistics in the output bootstrapping table (Table 6). The hypothesis test on the alpha score of 5\%, power score of $80 \%$, and one tail hypothesis, a hypothesis is supported when it has coefficient path score shown by Tstatistics equal or more than 1,64 (Abdillah \& Hartono, 2015).

\section{Analysis of The Result}

From the result of the research explained above, this study has confirmed the process related to the influence of sponsored post on Instagram social media towards the impulsive buying, with the process of signaling theory described by Spence (1973). In this case, the recommender or the owner or the user that is uploading a sponsored post is a signaler that would give a signal in the form of information through the sponsored post. The information in the sponsored post and then will be received by the Instagram user who is called a receiver with the help of sponsored post feature in the Instagram social media. The acceptance of the signal in the form of information by the Instagram user is expected to be a trigger of the urge to buy impulsively. It is consistent with the illustration of the signaling theory stated by Spence (1973). Spence (1973) illustrates the signaling theory model through the labor market where the potential worker acts as the signaler that give the signal in the form of information related to education and skill, which expected can be received by the employer that acts as a receiver. This potential worker also anticipating the signal delivered, that it can be an encourage the employer to choose them as the employee that suits the job vacancy. 


\section{Table 3: Output Criteria Overview Model}

\begin{tabular}{lcccccc}
\hline & AVE & $\begin{array}{l}\text { Composite } \\
\text { Reliability }\end{array}$ & R Square & Cronbachs Alpha & Communality & \multirow{2}{*}{ Redundancy } \\
\hline S & 0.797115 & 0.921761 & & 0.872538 & 0.797115 & \\
VE & 0.815128 & 0.929711 & & 0.886707 & 0.815128 & \\
AE & 0.829511 & 0.951094 & & 0.931285 & 0.829511 & \\
CT & 0.769676 & 0.909259 & 0.244286 & 0.850293 & 0.769676 & 0.187400 \\
AT & 0.790844 & 0.918662 & 0.489287 & 0.865401 & 0.790844 & 0.078248 \\
PA & 0.785479 & 0.936084 & 0.512117 & 0.909094 & 0.785479 & 0.133003 \\
UBI & 0.806163 & 0.925766 & 0.400335 & 0.879580 & 0.806163 & 0.002294 \\
\hline
\end{tabular}

Source: Processed by researcher

Notes: $\mathbf{S}=$ Similarity, $\mathrm{VE}=$ Vicarious Expression, $\mathrm{AE}=$ Aesthetic Appeal, $\mathrm{CT}=$ Cognitive Trust, $\mathrm{AT}=$ Affective Trust, PA = Product Affection, UBI = Urge to Buy Impulsively.

Table 4: Output Outer Loading

\begin{tabular}{|c|c|c|c|c|c|c|c|}
\hline $\begin{array}{c}\text { Indicator } \\
\text { S1 } \\
\text { S2 } \\
\text { S3 }\end{array}$ & $\begin{array}{c}\mathrm{S} \\
0.900443 \\
0.911149 \\
0.866231\end{array}$ & VE & $\mathrm{AE}$ & CT & AT & PA & UBI \\
\hline VE1 & & 0.901892 & & & & & \\
\hline VE2 & & 0.909651 & & & & & \\
\hline VE3 & & 0.896946 & & & & & \\
\hline AE1 & & & 0.867884 & & & & \\
\hline AE2 & & & 0.918556 & & & & \\
\hline $\mathrm{AE} 3$ & & & 0.931155 & & & & \\
\hline AE4 & & & 0.924136 & & & & \\
\hline CT1 & & & & 0.900782 & & & \\
\hline CT2 & & & & 0.853956 & & & \\
\hline CT3 & & & & 0.876572 & & & \\
\hline AT1 & & & & & 0.907608 & & \\
\hline AT2 & & & & & 0.946678 & & \\
\hline AT3 & & & & & 0.807826 & & \\
\hline PA1 & & & & & & 0.884807 & \\
\hline PA2 & & & & & & 0.889983 & \\
\hline PA3 & & & & & & 0.877809 & \\
\hline PA4 & & & & & & 0.892420 & \\
\hline UBI1 & & & & & & & 0.911296 \\
\hline UBI2 & & & & & & & 0.911764 \\
\hline UBI3 & & & & & & & 0.869893 \\
\hline
\end{tabular}

Source: Processed by researcher

Notes: $\mathrm{S}=$ Similarity, $\mathrm{VE}=$ Vicarious Expression, $\mathrm{AE}=$ Aesthetic Appeal, $\mathrm{CT}=\mathrm{Cognitive}$ Trust, $\mathrm{AT}=$ Affective Trust, $\mathrm{PA}=$ Product Affection, UBI = Urge to Buy Impulsively 
Table 5: Output Cross Loading

\begin{tabular}{cccccccc}
\hline Indicator & S & VE & AE & CT & AT & PA & UBI \\
\hline S1 & 0.900443 & 0.491774 & 0.420251 & 0.444477 & 0.41456 & 0.484604 & 0.415098 \\
S2 & 0.911149 & 0.436823 & 0.382007 & 0.405806 & 0.383878 & 0.485673 & 0.40804 \\
S3 & 0.866231 & 0.514519 & 0.398332 & 0.469904 & 0.380023 & 0.499069 & 0.39533 \\
VE1 & 0.457785 & 0.901892 & 0.40908 & 0.391771 & 0.389288 & 0.439402 & 0.305602 \\
VE2 & 0.453562 & 0.909651 & 0.474089 & 0.437983 & 0.401298 & 0.399071 & 0.354313 \\
VE3 & 0.554192 & 0.896946 & 0.561413 & 0.452869 & 0.357402 & 0.406877 & 0.316866 \\
AE1 & 0.341364 & 0.385079 & 0.867884 & 0.406036 & 0.392778 & 0.428862 & 0.367916 \\
AE2 & 0.419676 & 0.516562 & 0.918556 & 0.486108 & 0.429384 & 0.473044 & 0.425262 \\
AE3 & 0.443391 & 0.511592 & 0.931155 & 0.482571 & 0.42901 & 0.485015 & 0.413346 \\
AE4 & 0.425749 & 0.513564 & 0.924136 & 0.46858 & 0.432076 & 0.487793 & 0.429361 \\
CT1 & 0.417386 & 0.418963 & 0.449257 & 0.900782 & 0.642695 & 0.622498 & 0.463625 \\
CT2 & 0.414601 & 0.467969 & 0.487638 & 0.853956 & 0.563661 & 0.601192 & 0.44257 \\
CT3 & 0.466973 & 0.36269 & 0.40279 & 0.876572 & 0.607394 & 0.63493 & 0.513491 \\
AT1 & 0.422203 & 0.433743 & 0.433289 & 0.555294 & 0.907608 & 0.58039 & 0.4504 \\
AT2 & 0.412304 & 0.414943 & 0.460573 & 0.664263 & 0.946678 & 0.662252 & 0.543029 \\
AT3 & 0.338806 & 0.27585 & 0.332376 & 0.61722 & 0.807826 & 0.530081 & 0.409331 \\
PA1 & 0.468068 & 0.424399 & 0.469919 & 0.633613 & 0.559521 & 0.884807 & 0.501506 \\
PA2 & 0.501704 & 0.364235 & 0.43676 & 0.601006 & 0.573741 & 0.889983 & 0.480474 \\
PA3 & 0.496933 & 0.399876 & 0.390341 & 0.60235 & 0.59516 & 0.877809 & 0.528172 \\
PA4 & 0.481143 & 0.439383 & 0.522022 & 0.662976 & 0.633261 & 0.89242 & 0.589937 \\
UB11 & 0.42549 & 0.335392 & 0.409413 & 0.507321 & 0.482711 & 0.543246 & 0.911296 \\
UBI2 & 0.394752 & 0.323146 & 0.349565 & 0.446337 & 0.440914 & 0.508562 & 0.911764 \\
UBI3 & 0.404032 & 0.310257 & 0.447386 & 0.498175 & 0.49933 & 0.547998 & 0.869893 \\
\hline
\end{tabular}

Source: Processed by researcher

Notes: $\mathrm{S}=$ Similarity, $\mathrm{VE}=$ Vicarious Expression, $\mathrm{AE}=$ Aesthetic Appeal, $\mathrm{CT}=$ Cognitive Trust, $\mathrm{AT}=$ Affective Trust, $\mathrm{PA}=$ Product Affection, UBI = Urge to Buy Impulsively

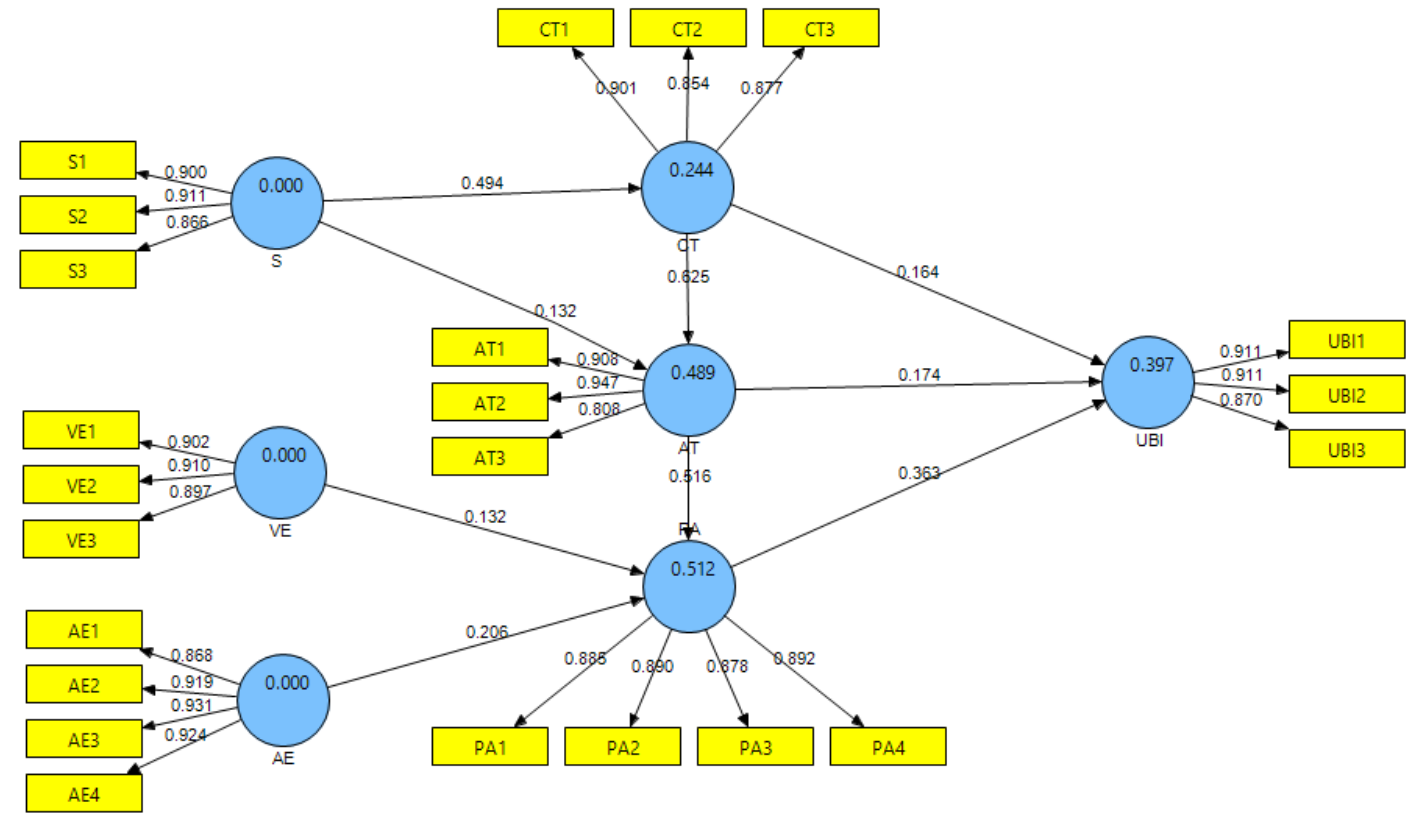

Figure 4: Output Research Model

Notes: $\mathrm{S}=$ Similarity, $\mathrm{VE}=$ Vicarious Expression, $\mathrm{AE}=$ Aesthetic Appeal, $\mathrm{CT}=$ Cognitive Trust, $\mathrm{AT}=$ Affective Trust, $\mathrm{PA}=$ Product Affection, UBI = Urge to Buy Impulsively 
Table 6: Output Bootstrapping

\begin{tabular}{ccccccc}
\hline & $\begin{array}{c}\text { Original } \\
\text { Sample } \\
(\mathrm{O})\end{array}$ & $\begin{array}{c}\text { Sample } \\
\text { Mean (M) }\end{array}$ & $\begin{array}{c}\text { Standard } \\
\text { Deviation } \\
(\text { STDEV })\end{array}$ & $\begin{array}{c}\text { Standard } \\
\text { Error } \\
(\text { STERR })\end{array}$ & $\begin{array}{c}\text { T Statistics } \\
(\mid \mathrm{O} / \text { STERR } \mid)\end{array}$ & Decision \\
\hline S -> AT & 0.131740 & 0.131177 & 0.072051 & 0.072051 & 1.828437 & Accepted \\
S -> CT & 0.494253 & 0.500279 & 0.064346 & 0.064346 & 7.681210 & Accepted \\
VE -> PA & 0.132027 & 0.147594 & 0.074697 & 0.074697 & 1.767513 & Accepted \\
AE -> PA & 0.206406 & 0.206896 & 0.079645 & 0.079645 & 2.591580 & Accepted \\
CT -> AT & 0.624939 & 0.621691 & 0.065758 & 0.065758 & 9.503604 & Accepted \\
AT -> PA & 0.516445 & 0.508257 & 0.071774 & 0.071774 & 7.195391 & Accepted \\
CT -> UBI & 0.157179 & 0.148738 & 0.109901 & 0.109901 & 1.430192 & Rejected \\
AT -> UBI & 0.183611 & 0.183473 & 0.088142 & 0.088142 & 2.083125 & Accepted \\
PA -> UBI & 0.351830 & 0.359144 & 0.099578 & 0.099578 & 3.533206 & Accepted \\
\hline
\end{tabular}

Source: Processed by researcher

Notes: $\mathrm{S}=$ Similarity, $\mathrm{VE}=$ Vicarious Expression, AE = Aesthetic Appeal, $\mathrm{CT}=$ Cognitive Trust, AT = Affective Trust, $\mathrm{PA}=$ Product Affection, UBI = Urge to Buy Impulsively

\section{CONCLUSION}

The data discovered in this study concludes that:

1. Similarity positively influences cognitive-trust and affective-trust. In this case, the more similarity between the Instagram user and the recommender, the more cognitive and affective trust of the Instagram user to the recommender.

2. Vicarious expression and aesthetic appeal positively influence product affection. In this case, the better the quality of the vicarious expression, and the more interesting the visual appearance of the sponsored post, the higher the affection of Instagram user to the product promoted in the sponsored post.

3. Cognitive trust positively influences affective-trust. In this case, the higher the Instagram user cognitive trust to the recommender, the higher their affective trust to the recommender.

4. Affective-trust positively influences product affection. In this case, the higher the affective trust of the Instagram user to the recommender, the higher their interest of the product promoted through the sponsored post.

5. Cognitive-trust is not influencing the urge to buy impulsively. In this case, the trust that is base on the rational thought (cognitive) of the Instagram user is not affecting their urge to buy impulsively.

6. Affective-trust and product affection positively influence the urge to buy impulsively. In this case, the higher the affective trust of the Instagram user to the recommender, and the higher their affection to the product promoted through the sponsored post, the higher their urge to buy impulsively.

Overall, the influence of the variables that are consist of similarity, vicarious expression, aesthetic appeal, cognitive and affective trust, product affection, and the urge to buy impulsively, are positively influenced. However, there is an exception for the test conducted to the influences between cognitive trust and the urge to buy impulsively. In this case, this study discovers that cognitive-trust that is base on rational thought of the individual is not influencing the urge to buy impulsively. Therefore, it can conclude that 
the urge to buy impulsively tend to influenced by individual emotion (affective) and the personal preference related to the product rather than their rational thought (cognitive).

\section{Discussion}

This study can describe the factors that can influence the urge of the Instagram user to buy impulsively. In this case, this study can be a consideration before or when promoting through social media, especially Instagram social media.

The result of this study shown that the similarity between the Instagram user and the sponsored post appear in their feed can influences their affective and cognitive trust to the recommender as the party who promote their product through a sponsored post. Other than that, in the Instagram social media that using photos, pictures, or videos in the form of the interaction, the factor like the aesthetic appeal is essential to be considered in the sponsored post. The caption feature that is the explanation which complements the content in the Instagram social media can be used, as the tool to tell the vicarious expression that can affect the Instagram user affection on the product promoted through a sponsored post. The factor of affective trust and product affection also discovered can influence the urge of the Instagram user to buy impulsively.

\section{Limitations}

The researchers realize that this study still has some limitations. The limitations of this study are that this study is depending on the Instagram feature used when this study conducted. In this case, the Instagram developer possibly done some change related to the Instagram feature. Other than that, in the research process, it is found that the sample is not the Instagram user, which does not match with the data needed. It affects the data collection method used in this study. Before the non-Instagram user found in the sample, the researcher using the random method as the data collection method. After the finding, the researcher uses the convenience sampling method in this study. The reason it becomes one of the limitations is that using a random sampling method is better. It is better because the random sampling method assessed as the method that is more representing the population than the convenience sampling method.

\section{REFERENCES}

Abdillah, W., \& Hartono, J. (2015). Partial Least Square (PLS): alternatif structural equation modeling (SEM) dalam penelitian bisnis. Yogyakarta: Penerbit Andi.

Adelaar, T., Chang, S., Lancendorfer, K. M., Lee, B., \& Morimoto, M. (2003). Effects of media formats on emotions and impulse buying intent. Journal of Information Technology, 18(4), 247-266.

Albarran, A. B. (2013). The social media industries. Routledge.

Beatty, S. E., \& Ferrell, M. E. (1998). Impulse buying: Modeling its precursors. Journal of Retailing, 74(2), 169-191.

Calefato, F., Lanubile, F., \& Novielli, N. (2015). The role of social media in affective trust building in customer-supplier relationships. Electronic Commerce Research, 15(4), 453-482. 
Chen, Y., Lu, Y., Wang, B., \& Pan, Z. (2019). How do product recommendations affect impulse buying? An empirical study on WeChat social commerce. Information \& Management, 56(2), 236-248.

Connelly, B. L., Certo, S. T., Ireland, R. D., \& Reutzel, C. R. (2011). Signaling theory: A review and assessment. Journal of Management, 37(1), 39-67.

Deighton, J., Romer, D., \& McQueen, J. (1989). Using drama to persuade. Journal of Consumer Research, 16(3), 335-343.

Dholakia, U. M. (2000). Temptation and resistance: an integrated model of consumption impulse formation and enactment. Psychology \& Marketing, 17(11), 955-982.

Hajli, N., Sims, J., Zadeh, A. H., \& Richard, M.-O. (2017). A social commerce investigation of the role of trust in a social networking site on purchase intentions. Journal of Business Research, 71, 133-141.

Hansen, D. R., \& Mowen, M. M. (2007). Managerial accounting 8 th edition: USA: Thomson South Western.

Hartono, J. (2013). Metodologi Penelitian Bisnis: Salah Kaprah dan PengalamanPengalaman (Edisi 6). Yogyakarta, Indonesia: BPFE UGM.

Hayashi, Y., \& Kryssanov, V. (2013). An empirical investigation of similarity-driven trust dynamics in social networks. Procedia-Social and Behavioral Sciences, 79, 27-37.

Horngren, C. T. (2012). Cost accounting : a managerial emphasis (14th ed.; S. M. Datar \& M. V Rajan, eds.). Upper Saddle River, N.J.: Pearson/Prentice Hall.

Huang, L.-S. (2015). Trust in product review blogs: the influence of self-disclosure and popularity. Behaviour \& Information Technology, 34(1), 33-44.

Isen, A. M. (1984). The influence of positive affect on decision making and cognitive organization. ACR North American Advances.

Johnson, D., \& Grayson, K. (2005). Cognitive and affective trust in service relationships. Journal of Business Research, 58(4), 500-507.

Lewicki, R. J., Tomlinson, E. C., \& Gillespie, N. (2006). Models of interpersonal trust development: Theoretical approaches, empirical evidence, and future directions. Journal of Management, 32(6), 991-1022.

Lewis, J. D., \& Weigert, A. (1985). Trust as a social reality. Social Forces, 63(4), 967985.

Li, M., Huang, L., Tan, C.-H., \& Wei, K.-K. (2013). Helpfulness of online product reviews as seen by consumers: Source and content features. International Journal of Electronic Commerce, 17(4), 101-136.

Mavlanova, T., Benbunan-Fich, R., \& Koufaris, M. (2012). Signaling theory and information asymmetry in online commerce. Information \& Management, 49(5), 240 247.

McEvily, B., Perrone, V., \& Zaheer, A. (2003). Trust as an organizing principle. Organization Science, 14(1), 91-103.

Morry, M. M. (2005). Relationship satisfaction as a predictor of similarity ratings: A test of the attraction-similarity hypothesis. Journal of Social and Personal Relationships, 22(4), 561-584.

Parboteeah, D. V., Valacich, J. S., \& Wells, J. D. (2009). The influence of website characteristics on a consumer's urge to buy impulsively. Information Systems Research, 20(1), 60-78. 
Park, E. J., Kim, E. Y., Funches, V. M., \& Foxx, W. (2012). Apparel product attributes, web browsing, and e-impulse buying on shopping websites. Journal of Business Research, 65(11), 1583-1589.

Sarstedt, M., Ringle, C., \& F. Hair, J. (2017). Partial Least Squares Structural Equation Modeling. https://doi.org/10.1007/978-3-319-05542-8_15-1

Scott, W. R. (2003). Financial accounting theory. Prentice Hall.

Sekaran, U. (2003). Research methods for business : a skill business approach.

Shaouf, A., Lü, K., \& Li, X. (2016). The Effect of Web Advertising Visual Design on Online Purchase Intention. Comput. Hum. Behav., 60(C), 622-634. https://doi.org/10.1016/j.chb.2016.02.090

Sofi, S. A., \& Nika, F. A. (2016). Measurement of Personality through Modified Instrument: A Study of Young Consumers of India. Asia-Pacific Journal of Management Research and Innovation, 12(2), 155-168. https://doi.org/10.1177/2319510X16680656

Spence, M. (1973). Job Market Signaling*. The Quarterly Journal of Economics, 87(3), 355-374. https://doi.org/10.2307/1882010

Xiao, S. H., \& Nicholson, M. (2013). A multidisciplinary cognitive behavioural framework of impulse buying: a systematic review of the literature. International Journal of Management Reviews, 15(3), 333-356.

Yoo, J., \& Kim, M. (2014). The effects of online product presentation on consumer responses: A mental imagery perspective. Journal of Business Research, 67(11), 2464-2472. 